BENM 2021

International Scientific and Practical Conference "Biotechnology, Ecology, Nature Management"

\title{
INCREASING THE EFFICIENCY OF INDUSTRIAL CRYSTALLIZATION OF SUCROSE
}

\author{
Natalia N. Lebedeva (a)*, Anatoliy A. Slavyanskiy (b), Vera A. Gribkova (c), \\ Natalia V. Nikolaeva (d) \\ *Corresponding author
}

(a) Department of Technology of products from plant raw materials and perfumery and cosmetic products, Federal State Budget Educational Institution of Higher Education «K.G. Razumovsky Moscow State University of technologies and management (the First Cossack University)», Moscow, Russia, mgutu-sahar@mail.ru

(b) Department of Technology of products from plant raw materials and perfumery and cosmetic products, Federal State Budget Educational Institution of Higher Education «K.G. Razumovsky Moscow State University of technologies and management (the First Cossack University)», Moscow, Russia

(c) Department of Technology of products from plant raw materials and perfumery and cosmetic products, Federal State Budget Educational Institution of Higher Education «K.G. Razumovsky Moscow State University of technologies and management (the First Cossack University)», Moscow, Russia

(d) Department of Technology of products from plant raw materials and perfumery and cosmetic products, Federal State Budget Educational Institution of Higher Education «K.G. Razumovsky Moscow State University of technologies and management (the First Cossack University)», Moscow, Russia

\begin{abstract}
The article discusses the process of industrial crystallization of sucrose, which includes three main stages (thickening of the syrup, the formation of crystallization centers and their growth). Depending on the method of crystal formation used, the technologies for obtaining massecuite I crystallization were analyzed, the improvement of which is due to the improvement of the conditions for the formation of crystallization centers, their growth, thickening of the massecuite masses and their separation in centrifuges. The disadvantage of the considered methods is the heterogeneity of obtaining sugar crystals, which is due to the use of powdered sugar for planting crystallization centers without special preparation, which ultimately reduces the yield efficiency and the quality of white sugar. In order to eliminate these disadvantages, a new method for producing white sugar was developed, which is characterized by the introduction of additional technological operations. In particular, the conditions for heating the steam chamber, maintaining the distance between the crystals, ensuring the minimum viscosity of the massecuite and the requirements for the process of separating the massecuite in a centrifuge have been specified. The results of the studies made it possible to clarify the technological solutions and parameters of the massecuite I crystallization boiling, and the sugar yield according to the new method after boiling and centrifuging the massecuite I crystallization increased by $1.5 \%$ to the mass of the massecuite.
\end{abstract}

2672-8575 (C) 2022 Published by European Publisher.

Keywords: Cliff, centers of crystallization, crystallization, sucrose, vacuum apparatus 


\section{Introduction}

The process of industrial crystallization of sucrose includes three main stages: thickening of the syrup, nucleation of crystals and their growth. Under industrial conditions, sucrose crystallizes in massecuite boiled under vacuum. Its crystals in a massecuite mass are in cramped conditions in a viscous intercrystalline solution, which significantly affects the crystallization rate (Slavyansky, 2012).

A typical technology for the operation of the food department of a sugar factory provides for the production of white sugar in three crystallization stages. In this case, crystalline white sugar is obtained on the first of them by boiling the massecuite of the first product. It is recommended to boil massecuite I crystallization from a mixture of syrup with clearing of sugars II and III products (Slavyansky, 2006). Moreover, this process can be divided into several technological operations, shown in Figure 1 (Sapronov et al., 2015).

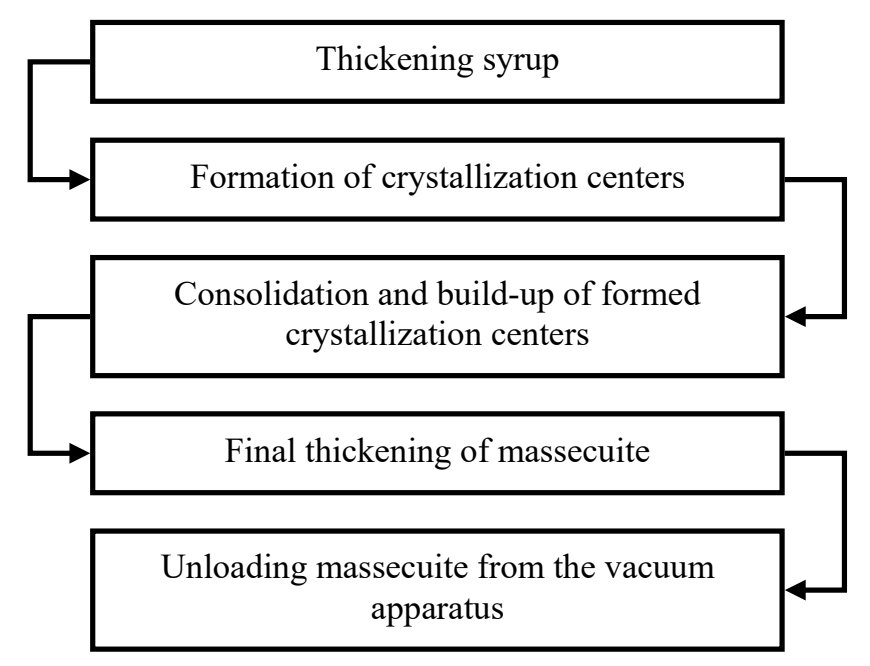

Figure 1. The main stages of crystallization of sucrose in a vacuum apparatus

The mass of syrup with clearing, condensed to a state of supersaturation, and the rate of formation of crystallization centers in it determine further the kinetics of industrial crystallization of sucrose. In this case, the process of crystallization of sucrose in vacuum apparatus proceeds most intensively, provided that the rate of evaporation of water is close to the rate of crystal growth under these conditions.

The formation of sucrose crystals in supersaturated solutions should be preceded by the appearance of their nuclei (crystalline centers), which would have the possibility of further growth (Slavyansky, Semenov et al., 2015).

\section{Purpose of the Study}

Currently, there are many ways to improve the technology of obtaining massecuite I crystallization by improving the conditions for the formation of crystallization centers, their growth, thickening massecuite masses and their separation in centrifuges. Such developments, for example, include a method 
for the production of white sugar, which provides for the thickening of the syrup, the formation of crystallization centers in it at the rate of 10-12 pieces. per $1 \mathrm{~mm}$ of the length of the surface of the test glass, their build-up to $0.2-0.3 \mathrm{~mm}$ in the first vacuum apparatus, the selection of a part of the massecuite in the amount of $50-55 \%$ of its total mass and feeding into the second vacuum apparatus, boiling the massecuite in the first and the second apparatus until ready, the descent of massecuite into the receiving massecuite mixer and centrifugation with the selection of the first overflow, washing the sugar crystals with the separation of the second overflow and unloading the sugar crystals from the centrifuge (Tuzhilkin et al., 1983).

The disadvantage of this method is the heterogeneity of obtaining sugar crystals, which is due to the use of powdered sugar for planting crystallization centers without special preparation. As a rule, it is taken from the drying department, it has a non-uniform granulometric composition. This is due to the fact that powdered sugar crystals contain a lot of debris and chips of sugar crystals, as well as their various intergrowths and aggregates.

Recently, in order to eliminate the disadvantages caused by the use of powdered sugar and some seed pastes, it is recommended to use the uterine massecuite when boiling the massecuite I crystallization. The use of uterine massecuite consists in the formation and consolidation of sugar crystals in a special cooling crystallizer under certain conditions, their build-up at supersaturation of 1.05-1.10 to sizes of 0.1$0.2 \mathrm{~mm}$, and further build-up in a separate vacuum apparatus during boiling up to $0.2-0.35 \mathrm{~mm}$. The use of uterine massecuite provides a more uniform granulometric composition of sugar crystals, which makes it possible to increase the sugar yield and reduce the consumption of wash water (Slavyansky, Sergeeva et al., 2013).

Such methods of producing white sugar include a technology where master massecuite with a crystal size of $0.12-0.16 \mathrm{~mm}$ is used as crystallization centers. Moreover, the centers of crystallization are increased to the content of $88.0-90.0 \%$ of dry substances in the massecuite. After that, part of the massecuite from this apparatus in the amount of $30-40 \%$ of the total mass is taken in a mixture with syrup and melting into a second vacuum apparatus as a crystalline base. In the first apparatus, massecuite is boiled down to $92.0-92.5 \%$ of dry matter, and in the second, up to $93.0-93.5 \%$ of dry matter. The massecuite from the first vacuum apparatus is sent for centrifugation 50-60 minutes earlier than the second. Washing of sugar crystals is carried out in two stages - first with a sugar-containing solution with a concentration of $70-76 \%$ of dry substances in an amount of $2.5-3.5 \%$ to the massecuite mass at a temperature of $70-90^{\circ} \mathrm{C}$, and then with steam at its pressure of $0.3-0.4 \mathrm{MPa}$ in the amount of $1.5-2.0 \%$ to the mass of massecuite (Slavyansky, Sergeeva et al., 2013).

The disadvantages of this method include not quite clearly substantiated operations of the process of boiling massecuite in a vacuum apparatus and its subsequent separation in the field of centrifugal forces, which reduces the efficiency of the yield and the quality of white sugar.

\section{Research Methods}

In order to eliminate these disadvantages, this method has been improved by introducing additional technological operations into it. In particular, the conditions for heating the steam chamber, maintaining the distance between the crystals, ensuring the minimum viscosity of the massecuite and the 
requirements for the process of separating the massecuite in a centrifuge have been specified (Slavyansky, 2007).

As in the known method, master massecuite with a crystal size of $0.12-0.16 \mathrm{~mm}$ was used as crystallization centers. The crystals were grown when the massecuite was thickened to $88.0-90.0 \%$ of dry matter at a temperature of $72-76^{\circ} \mathrm{C}$ and the steam chamber of the vacuum apparatus was heated with steam at a temperature of $105-110^{\circ} \mathrm{C}$. Under such heating conditions, the maximum crystal growth rate was ensured with minimal inclusions of non-sugars, especially dyes. In addition, at these temperature parameters, a high useful temperature difference between the heating steam and the boiling solution was ensured, which made it possible to reduce the loss of sucrose from thermal decomposition.

Then part of the massecuite from the first vacuum apparatus in the amount of 30-40\% of the total massecuite mass was taken in a mixture with syrup and melting into the second vacuum apparatus as a crystalline base.

Moreover, in the first and second vacuum apparatus the massecuite was boiled down to the content of crystals in it in the range of 50-55\%, keeping the distance between the crystals equal to $1.5 \cdot 10-4-2.5$ - 10-4 $\mathrm{m}$ during the boiling process. boiling massecuite from the first apparatus is directed to centrifugation earlier than from the second vacuum apparatus. Before centrifugation, the temperature of the massecuite is brought to $68-72{ }^{\circ} \mathrm{C}$ to ensure its minimum viscosity in a centrifugal force field (Slavyansky, Semenov, et al., 2017).

The sugar crystals are washed in two stages. First, they are treated with a sugar-containing solution with a concentration of $70-75 \%$ dry matter. In this case, the separation of the first outflow is accompanied by the introduction of moisture-saturated air into the centrifuge rotor with a temperature higher than that of massecuite by $2-5^{\circ} \mathrm{C}$. The use of a sugar-containing solution for washing crystals with a concentration of $70-75 \%$ of dry substances makes it possible to reduce their dissolution in comparison with washing with hot water. In addition, the sugar-containing solution in the specified concentration range makes it possible to more completely displace the remnants of the intercrystalline solution from the crystal layer and reduce the thickness of its film on their surface.

In addition, this method involves the use of wash water saturated with ozone at the rate of 5-10 mg $/ 1$ in an amount of $1.0-1.2 \%$ by weight of massecuite.

The introduction of moisture-saturated air into the rotor of the centrifuge with a temperature higher than that of massecuite by $2-5^{\circ} \mathrm{C}$ helps to reduce the viscosity of the intercrystalline solution separated from the crystals, as well as its films on the crystals themselves. Ozonation of wash water significantly affects the removal of coloring matter from sugar crystals (Slavyansky, Lebedeva, et al., 2018).

\section{Findings}

To compare the proposed method with the known, the following indicators were determined: the purity of the massecuite of the first crystallization in the first and second vacuum apparatuses (\%), the content of dry substances in them (\%), the average yield of sugar crystals from centrifuges for two massecuite I crystallization (\% to the mass of massecuite); physicochemical indicators of the quality of crystalline white sugar: chromaticity (optical units), turbidity (physical units), the content of reducing 
substances (\%), ash content (\%), granulometric indicators sugar: average crystal size (mm), coefficient of heterogeneity (\%).

The research results on the proposed and known methods are presented in the Table 1.

Table 1. Average results of boiling massecuite I crystallization

\begin{tabular}{|c|c|c|}
\hline \multirow{2}{*}{ Showing } & \multicolumn{2}{|c|}{ Method } \\
\hline & Known & Proposed \\
\hline \multicolumn{3}{|l|}{ Technological indicators } \\
\hline \multicolumn{3}{|l|}{ Purity of massecuite of the first crystallization, $\%:$} \\
\hline - in the first vacuum apparatus & 91.83 & 91.80 \\
\hline - in the second vacuum apparatus & 91.51 & 91.50 \\
\hline The dry matter content of the massecuite of the first crystallization, $\%$ : & & \\
\hline - in the first vacuum apparatus & 92.22 & 92.25 \\
\hline - in the second vacuum apparatus & 92.87 & 92.25 \\
\hline $\begin{array}{l}\text { Average yield of sugar crystals from a centrifuge for two massecuite of } \\
\text { the first crystallization, } \% \text { to the mass of massecuite }\end{array}$ & 50.1 & 51.6 \\
\hline \multicolumn{3}{|l|}{$\begin{array}{ll} & \text { Physical and chemical indicators } \\
\end{array}$} \\
\hline Color, units wholesale pl. & 104 & 95.5 \\
\hline Turbidity, physical units & 28.8 & 19.1 \\
\hline The content of reducing substances, $\%$ & 0.052 & 0.027 \\
\hline Ash content, \% & 0.037 & 0.020 \\
\hline \multicolumn{3}{|l|}{ Granulometric indicators } \\
\hline Average crystal size, $\mathrm{mm}$ & 0.69 & 0.72 \\
\hline Coefficient of heterogeneity, $\%$ & 29.1 & 24.8 \\
\hline
\end{tabular}

\section{Conclusion}

From the given data on the implementation of the proposed method, in comparison with the known one, it can be seen that the sugar yield according to the new method after boiling and centrifugation of the massecuite of the first crystallization increased by $1.5 \%$ to the mass of the massecuite. In addition, the resulting crystalline white sugar has slightly better physicochemical quality indicators, as well as its granulometric composition. Therefore, with its use, a higher efficiency of boiling and separation of massecuite I crystallization in a centrifugal force field is achieved.

\section{References}

Sapronov, A. R., Sapronova, L. A., \& Ermolaev, S. V. (2015). Sugar technology. Publishing House "Profession".

Slavyansky, A. A. (2006). Technological equipment for sugar factories: classification, technical characteristics, calculations, layout. MGUPP.

Slavyansky, A. A. (2007). Centrifugation and its influence on the yield and quality of sugar. MGUPP.

Slavyansky, A. A. (2012). Sugar: purpose, properties and production. MGUTU.

Slavyansky, A. A., Semenov, E. V., \& Lebedeva, N. N. (2015). Crystallization centers and their formation in a sugar-containing solution. Technology and commodity science of innovative food products, 2, 3-11.

Slavyansky, A. A., Lebedeva, N. N., Cheremisina, A. Y., \& Gorbachev, A. V. (2018). Method for the production of crystalline white sugar Patent RU. 
Slavyansky, A. A., Semenov, E. V., Lebedeva, N. N., \& Cheremisina, A. Y. (2017). Innovations in the field of boiling the massecuite of the first crystallization in Collection of scientific articles and reports of the III International Scientific and Practical Conference "Innovative Solutions in the Production of Food Products from Plant Raw Materials" (pp. 803-810). Voronezh: VGUIT.

Slavyansky, A. A., Sergeeva, E. A., \& Makarova, S. A. (2013). Method for the production of crystalline white sugar Patent RU 2544596.

Tuzhilkin, V. I., Karagodin, M. A., \& Sapronov, A. R. (1983). Method of boiling sugar massecuite Patent SU. 